\title{
Analysis of Boundary between Donggala Regency- Central Sulawesi and Mamuju Utara Regency- West Sulawesi Using Cartometric Method
}

\author{
Zahratu Firdaus, Yuwono, and Yanto Budisusanto
}

\begin{abstract}
Since the implementation of a vast autonomous region, real and responsible under law No. 22 of year 1999 about the local governance that is then replaced Act No. 23 of the year 2014, the boundary between the areas of concern that It is very important. In the era of regional autonomy, lots of good developments in the area of the village, district/city or province which holds the expansion. In practice, many local governments have trouble setting the boundaries of the region. One of them, namely the area between the boundaries of Donggala Regency North Mamuju and. The conflict limit the area of Donggala and Mamuju Regency North appeared as a result of the existence of a policy based on the area boundary Setup Kepmendagri No. 52 Year 1991 especially after installation of the Monument/Peg Limits on the area of the border between Donggala Regency North Mamuju less involving local communities.The purpose of this research is to provide a new boundary line between the Donggala Regency North Mamuju and. Determination of the limits of this area using the appropriate kartometrik method Permendagri No. 76 Year 2012 about the guideline Assertion Limit area. From the results of the analysis of the territorial boundaries of the second district, obtained a map of territorial boundaries which allows alternatives to be used as consideration of dispute resolution in Donggala Regency and North Mamuju Regency.
\end{abstract}

Keywords-Cartometric Method, Regional Borders, Boundary Dispute.

\section{INTRODUCTION}

Since the implementation of broad regional autonomy, real and responsible based on Law no. 22 of 1999 on Regional Government which was then replaced by Law no. 32 of 2004 and the most recent Law no. 23 Year 2014, boundaries between regions become a very important concern. In the era of regional autonomy, there are a lot of regional developments in both the villages, districts / municipalities and provinces that have split up. This has resulted in potential conflicts between regions and even a political impact on border areas. In practice, many local governments have difficulty setting borders. After the implementation of regional autonomy, problems that often arise both between autonomous regions and in an autonomous region is the issue of border area [1]. One of them is the boundary between Donggala Regency and North Mamuju Regency.

In the province of Central Sulawesi, there is a case of Ngovi Village area, this area boundary conflict arises as a result of

Zahratu Firdaus, Yuwono, and Yanto Budisusanto are with Department of Geomatics Engineering, Institut Teknologi Sepuluh Nopember, Surabaya, 60111, Indonesia. E-mail: zahratusiradz@gmail.com. the policy of regional border arrangement based on Kepmendagri no. 52 Year 1991, especially after the benchmark in the border area between Donggala District and North Mamuju Regency which less involving the local community. Legally based on Law No. 26 Year 2004 concerning Pemekaran of West Sulawesi Province, the area claimed to enter the North Mamuju region of West Sulawesi Province. Administratively, the claim area is recognized by Donggala Regency of Central Sulawesi Province as part of its territory.

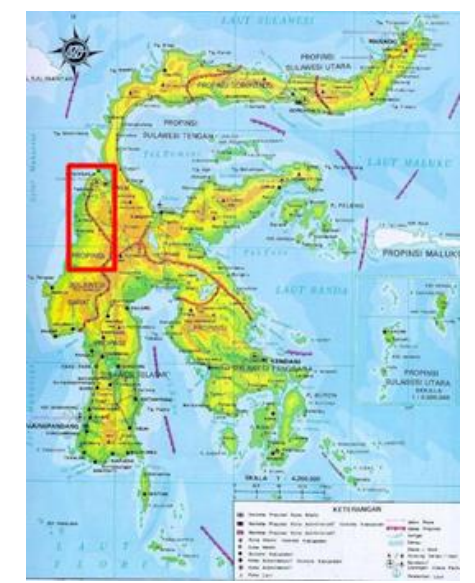

Figure 1. Research Sites (Mappery, 2014).

This study aims to provide a recommendation of the boundary line between Donggala Regency Central Sulawesi Province with North Mamuju Regency West Sulawesi Province. Boundary determination can be done using two methods: cartometric method (withdrawal on work map) and field survey method [2]. This research uses the cartometric method, this method can reduce the survey activity in the field which usually requires a large amount of funds and a relatively long time, especially in difficult terrain that is difficult to reach because of the natural barrier itself, making the work of technicalboundary conflicts can be done in a long time shorter without reducing the required accuracy.

Confirmation of boundaries is a definite boundary activity in the field. The border affirmation process focuses on the realization of clear and definite boundaries both from the juridical and physical aspects of the field and is done in order to determine the exact position and boundary position in the field up to the determination of the boundary coordinate point above the map [3]. 


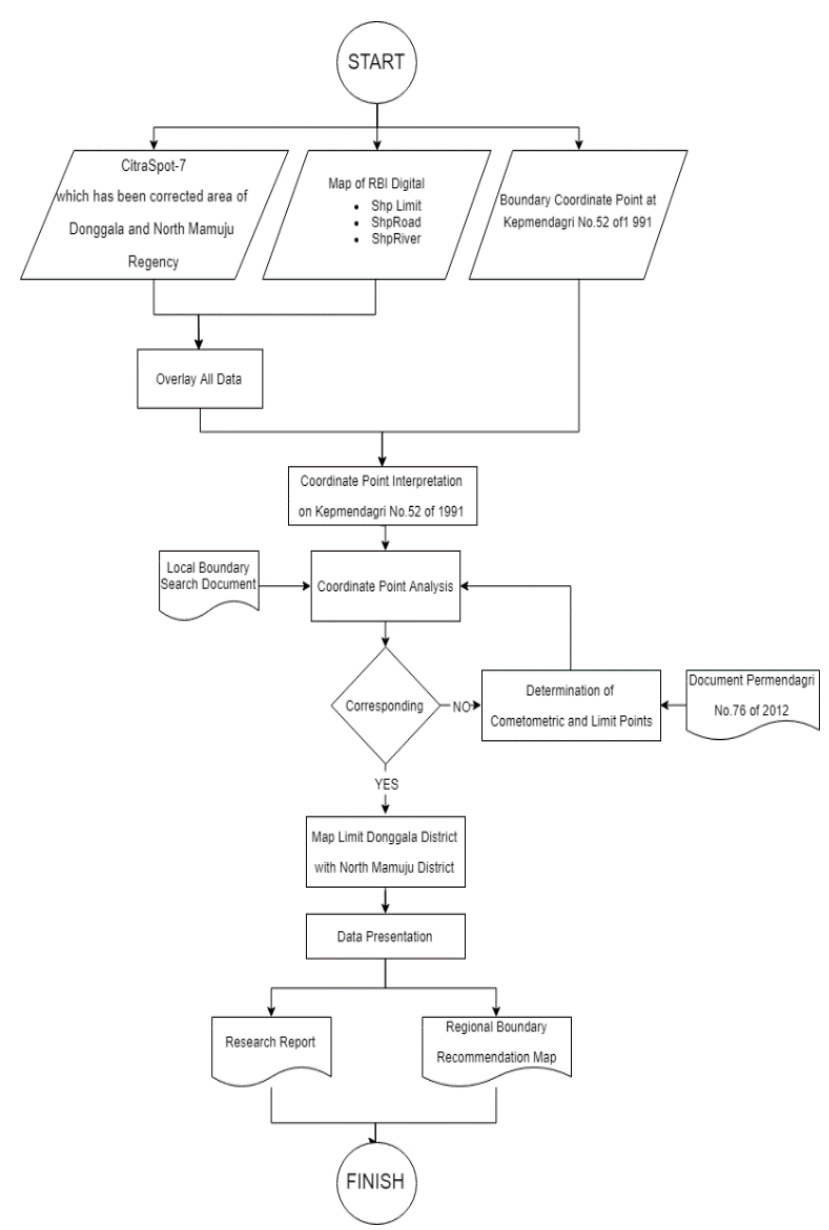

Figure 2. Flowchart of Processing Data.

\section{Methodology}

\section{A. Research Location}

Research location in Donggala District, Central Sulawesi Province with coordinates $0^{\circ} 40$ '42"LU - $2^{\circ} 30^{\prime} 20^{\prime \prime} \mathrm{LS}$ and $119^{\circ} 45^{\prime} 9^{\prime \prime}-121^{\circ} 45^{\prime} 24^{\prime \prime}$ BT and North Mamuju Regency of West Sulawesi province, with coordinates of $0^{0} 40^{\prime} 10^{\prime \prime}$ $10^{\circ} 50^{\prime} 12^{\prime \prime} \mathrm{S}$ and $119^{0} 25^{\prime}$ '26" - $119^{0} 50^{\prime}$ '20" BT (Kemendagri 2016) (Figure 1).

\section{B. Data and Material}

Data required in this study were obtained from the Geospatial Information Agency (BIG) consisting of:

1. High-resolution satellite images SPOT-7 (Satellite Pour l'Observtion de la Terre - 7) 2014/2015

2. Digital RBI Map of the boundary of Donggala County and North Mamuju Regency scale 1: 50,000 in 2016

3. The data of border pillar coordinates of Kepmendagri No. 52 of 1991

4. Permendagri No. 76 of 2012 on the confirmation of regional boundaries

\section{Stages of Data Processing}

The data processing from this research can be explained as follows:

1. Data Collection

2. There are some data that must be collected in this research process namely Spot-7 image that has been corrected in 2014/2015 and Digital RBI Map

3. Overlay of RBI Image and Map Data

4. Both RBI image and map data are overlaid or overlayed to match the view between the image and the RBI map. Overlay is to override a digital map on another digital map along with its attributes and produce a composite map of both of which has attribute information from both maps.

5. Kepmendagri Coordinate Point Analysis

6. To analyze the result from the coordinate point of Kepmendagri no. 52 of 1991 in accordance with permendagri no. 76 of 2012.

7. Determination of Cometometric Points

8. The determination of the cartometric point on the boundary line is done using the cartometric method referring to the Minister of Home Affairs Regulation No. 76/2012 concerning the withdrawal of the boundary line.Creating Cruise line.

9. Presentation of data that is showing

10. alternative map line donggala district with north mamuju district.

\section{RESULT AND DISCUSSION}

\section{A. Results of Area Boundary Interpretation}

The interpretation result of Kepmendagri coordinate no. 52 Year 1991 can be seen in Figure 3. Figure 3 shows the boundary line of Donggala District with North Mamuju Regency according to the interpretation of Kepmendagri no. 52 of 1991 . The blue line represents the boundary through the river, while the brown line represents the boundary that passes through the ridge (contour). The drawing of Kepmen line is done by field survey method and cartometric method.

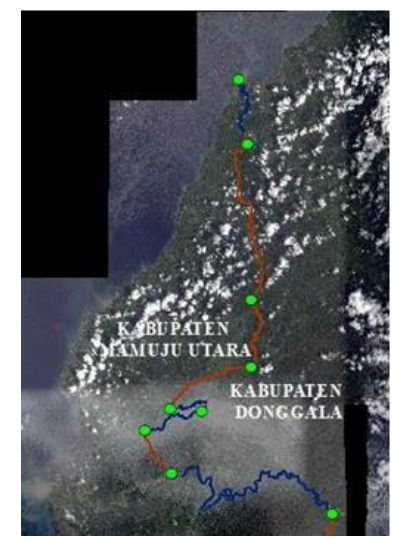

Figure 3. Interpretation of Kepmendagri Limits 52/1991. 


\section{B. Results of the Limit Recommendation}

In this research, the boundary maps of Donggala Districts and North Mamuju Districts can be used as recommendations for the settlement of the border disputes between the two regions. The area in this study was in the $50 \mathrm{~S}$ zone. Boundaries can be drawn based on natural markers (eg river), artificial markers (eg roads), and other agreed boundary markers.

The results of this study are based on the Minister of Home Affairs Regulation no. 76 of 2012 on the confirmation of regional boundaries. As in the map contains some information such as administrative boundaries, the location of the point kartometrik and so forth. An alternative map of borders for more details can be seen in the appendix of this paper.

The analysis done in this research is to fix the boundary area according to Kepmendagri no. 52 year 1991 based on Permendagri no. 76 Year 2012. The following sample analysis on the boundary line:

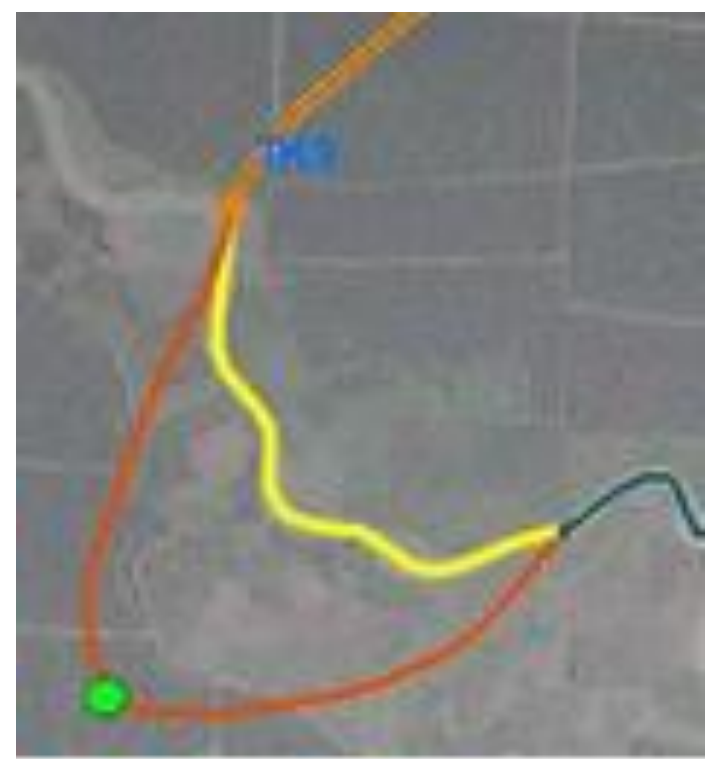

Figure 4. Boundary Line Improvement

Figure 4 is one example of the old line drawing (Kepmen 52/1991) to the new (Permen 76/2012) on a cartometric basis. The red line is the boundary line of Kepmendagri $52 / 1991$ that is fixed as shown on the yellow line that follows the natural boundary of a river [2].

Research Analysis Of Literature Data

1. Legal Aspect, Kepmendagri No. 52 of 1991 on the affirmation of the boundary line between the provincial level I South Sulawesi with the province of the region I level Central Sulawesi.

2. Administration Aspect, Ngovi residents mostly have identity cards (KTP) in the district of Donggala Central Sulawesi Province.

3. Geographical Aspect, The distance or access point of Ngovi Village to the Donggala District Administration Office is approximately $79 \mathrm{~km}$. While the distance from North Mamuju Regency approximately $30 \mathrm{~km}$ from the administrative office of government.

\section{Description of Area Borders Segment}

The boundary line in this study is the legal boundary line (Permendagri 76/2012). The border line is guided by the Minister of Home Affairs Regulation no. 76 Year 2012 [2]. The resulting boundary is sourced from digital RBI data (contour, river, road) and Citra. The following table describes the description of each boundary line,

TABLE 1.

INFORMATION FROM THE SEGMENT BOUNDARY

\begin{tabular}{|c|c|c|c|}
\hline No & Data Source & Description & TK Interval \\
\hline 1 & RBI Map 2016 & $\begin{array}{l}\text { Natural Boundary } \\
\text { Segments including } \\
\text { mountain ridges using } \\
\text { contour data }\end{array}$ & TK4 - TK5 \\
\hline 2 & RBI Map 2016 & $\begin{array}{l}\text { Natural Boundary } \\
\text { Segments including } \\
\text { mountain ridges using } \\
\text { contour data }\end{array}$ & TK6 - TK7 \\
\hline 3 & $\begin{array}{c}\text { SPOT-7 } \\
\text { Imagery } \\
2014 / 2015\end{array}$ & $\begin{array}{l}\text { The natural boundary } \\
\text { segment is a river }\end{array}$ & TK9 - TK10 \\
\hline 4 & $\begin{array}{c}\text { SPOT-7 } \\
\text { Imagery } \\
2014 / 2015\end{array}$ & $\begin{array}{l}\text { The natural boundary } \\
\text { segment is a river }\end{array}$ & TK11 - TK12 \\
\hline 5 & $\begin{array}{c}\text { SPOT-7 } \\
\text { Imagery } \\
2014 / 2015\end{array}$ & $\begin{array}{l}\text { The natural boundary } \\
\text { segment is a river }\end{array}$ & TK14 - TK15 \\
\hline 6 & $\begin{array}{c}\text { SPOT-7 } \\
\text { Imagery } \\
2014 / 2015\end{array}$ & $\begin{array}{l}\text { The natural boundary } \\
\text { segment is a river }\end{array}$ & TK2 \\
\hline 7 & RBI Map 2016 & $\begin{array}{l}\text { Natural Boundary } \\
\text { Segments including } \\
\text { mountain ridges using } \\
\text { contour data }\end{array}$ & $\mathrm{TK} 2-\mathrm{TK} 4$ \\
\hline 8 & $\begin{array}{l}\text { SPOT-7 } \\
\text { Imagery } \\
2014 / 2015\end{array}$ & $\begin{array}{l}\text { Boundary Segments } \\
\text { are roads }\end{array}$ & TK5 - TK6 \\
\hline 9 & $\begin{array}{c}\text { SPOT-7 } \\
\text { Imagery } \\
2014 / 2015\end{array}$ & $\begin{array}{l}\text { Boundary Segments } \\
\text { are roads }\end{array}$ & TK1 - TK2 \\
\hline 10 & $\begin{array}{c}\text { SPOT-7 } \\
\text { Imagery } \\
2014 / 2015\end{array}$ & $\begin{array}{l}\text { Boundary Segments } \\
\text { are roads }\end{array}$ & TK2 - TK3 \\
\hline 11 & RBI Map 2016 & $\begin{array}{l}\text { Natural Boundary } \\
\text { Segments including } \\
\text { mountain ridges using } \\
\text { contour data }\end{array}$ & TK4 \\
\hline 12 & Non-Fitur & Non-Fitur & TK10 - TK11 \\
\hline 13 & Non-Fitur & Non-Fitur & TK13 - TK14 \\
\hline 14 & $\begin{array}{c}\text { SPOT-7 } \\
\text { Imagery } \\
2014 / 2015\end{array}$ & $\begin{array}{l}\text { The natural boundary } \\
\text { segment is a river }\end{array}$ & TK7 - TK8 \\
\hline $\begin{array}{l}15 \\
16\end{array}$ & $\begin{array}{l}\text { Non-Fitur } \\
\text { SPOT-7 } \\
\text { Imagery } \\
2014 / 2015\end{array}$ & $\begin{array}{l}\text { Non-Fitur } \\
\text { Boundary Segments } \\
\text { are roads }\end{array}$ & $\begin{array}{c}\text { TK8 - TK9 } \\
\text { TK12 - TK13 }\end{array}$ \\
\hline
\end{tabular}

\section{Result of Boundary Cartometric Points}

TABLE 2.

PROVINCIAL AND DISTRICT CODES

\begin{tabular}{cccc}
\hline \hline Code & Province Name & Code & District Name \\
\hline 72 & Sulawesi Tengah & 01 & Mamuju Utara \\
\multirow{2}{*}{76} & Sulawesi Barat & 02 & Mamuju \\
& & 03 & Donggala \\
\hline \hline
\end{tabular}


IPTEK Journal of Proceedings Series No. (2) (2019), ISSN (2354-6026)

The $3^{\text {rd }}$ Geomatics International Conference 2018

July $12^{\text {th }} 2018$, Institut Teknologi Sepuluh Nopember, Surabaya, Indonesia

TABLE 3.

GRADIENT RESULT

\begin{tabular}{cccc}
\hline \hline Code & Sub-District & Village & TK Code \\
\hline 02 & Pasangkayu & Malino & 76.02 .11 .2007 \\
04 & Rio Pakava & Bambalamo & 76.01 .01 .1006 \\
09 & Pedongga & Polewali & 76.01 .01 .2003 \\
11 & Tommo & Martajaya & 76.01 .02 .1002 \\
& & Martasari & 76.01 .09 .2004 \\
& & Pasangkayu & 76.01 .02 .1001 \\
& & Lalundu & 72.03 .04 .2004 \\
& & Tikke & 76.01 .08 .2001 \\
& & Baras & 76.01 .03 .1001 \\
\hline \hline
\end{tabular}

TABLE 4.

DATUM TRANSFORMATION

\begin{tabular}{|c|c|c|c|}
\hline \multirow{2}{*}{ No } & \multirow{2}{*}{$\begin{array}{c}\text { Cartometric } \\
\text { Point } \\
\end{array}$} & \multicolumn{2}{|c|}{ Coordinate } \\
\hline & & $X(m)$ & $Y(m)$ \\
\hline \multirow{2}{*}{1} & TK76.01.11.2001 & \multirow{2}{*}{785041.264094} & \multirow{2}{*}{9906091.75941} \\
\hline & $-02.11 .2007-001$ & & \\
\hline \multirow{2}{*}{2} & TK76.01.11.2001 & \multirow{2}{*}{785837.689282} & \multirow{2}{*}{9898625.74887} \\
\hline & $-02.11 .2007-002$ & & \\
\hline \multirow{2}{*}{3} & TK76.01.11.2001 & \multirow{2}{*}{786429.141617} & \multirow{2}{*}{9897332.58608} \\
\hline & $-02.11 .2007-003$ & & \\
\hline 4 & $\begin{array}{c}\text { TK76.01.11.2001 } \\
-01.1006-004\end{array}$ & 784392.869700 & 9895363.46320 \\
\hline 5 & $\begin{array}{c}\text { TK76.01.11.2001 } \\
-01.1006-005\end{array}$ & 788469.785473 & 9875887.75330 \\
\hline 6 & $\begin{array}{c}\text { TK76.01.01.2003 } \\
-02.1002-006\end{array}$ & 787288.105103 & 9871534.13977 \\
\hline 7 & $\begin{array}{c}\text { TK76.01.02.1002 } \\
-09.2004-007\end{array}$ & 783408.946520 & 9861422.73933 \\
\hline 8 & $\begin{array}{c}\text { TK76.01.02.1002 } \\
-02.1001-008\end{array}$ & 779862.080265 & 9862054.21376 \\
\hline 9 & $\begin{array}{c}\text { TK76.01.09.2004 } \\
-02.1001-009\end{array}$ & 774475.719900 & 9856398.37940 \\
\hline 10 & $\begin{array}{c}\text { TK72.03.04.2004 } \\
-010\end{array}$ & 779682.738434 & 9856001.48511 \\
\hline 11 & $\begin{array}{c}\text { TK76.01.09.2004 } \\
-08.2001-011\end{array}$ & 779377.661793 & 9854804.88044 \\
\hline 12 & $\begin{array}{c}\text { TK76.01.09.2004 } \\
-08.2001-012\end{array}$ & 769705.178317 & 9851666.70900 \\
\hline 13 & $\begin{array}{c}\text { TK76.01.09.2004 } \\
-08.2001-013\end{array}$ & 770396.462699 & 9850444.65086 \\
\hline 14 & $\begin{array}{c}\text { TK76.01.09.2004 } \\
-08.2001-014\end{array}$ & 774004.318468 & 9845443.65475 \\
\hline 15 & $\begin{array}{c}\text { TK76.01.08.2001 } \\
-03.1001-015\end{array}$ & 800039.307763 & 9839447.86680 \\
\hline
\end{tabular}

Obtained 15 points kartometrik spread on the boundary line of Donggala and North Mamuju. Table 2 and Table 3 show the area codes according to Permendagri No. 56 of 2015 on the Code and Data of Regional Government Administration. Figure 5 shows the distribution of the cartometric point on the alternate line.

Table 4 shows the coordinates of kindergarten and numbering in kindergarten. According to Minister of Home Affairs Regulation no. 45 of 2016 Concerning Guidelines for Determining and Affirmation of Village Borders, for numbering of cartometric points is TK (provincial area code). (District code of district) 1 (district code of village 1) -. (area

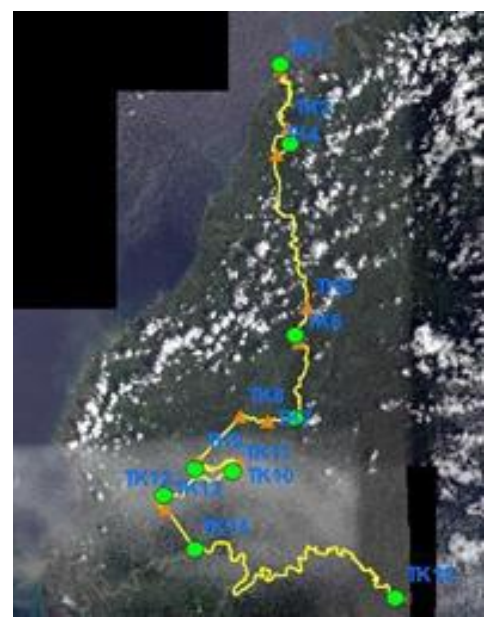

Figure 5. Spread of the Kartometric Points

code of the 2nd district). (code of village area / kelurahan ke2) number of kartometric point.

The determination of the cartometric point is done by the extraction process of coordinate points based on the delineation boundary line. The determination of the cartometric point is done in accordance with the specified technical specifications. The determination of the cartometric point directly above the work map and can use the help of digital work maps if the area can not be interpreted. The cartometric point is placed at each turn of the boundary type from the natural boundary to the artificial boundary or vice versa [2].

\section{CONCLUSSION}

The conclusion of research of boundary of Donggala Regency of Central Sulawesi Province wih Regency of North Mamuju West Sulawesi Province is to produce alternative map of area boundary with scale 1: 500000 determined by cartometric method. The length of the boundary generated from this alternative map is $145562.073 \mathrm{~m}$ for the natural boundary line whereas $28059.417 \mathrm{~m}$ for the artificial boundary line. This study yielded 15 cartometric points located along the boundary line of Donggala Regency and North Mamuju Regency.

\section{REFERENCES}

[1] S. Joyosumarto, "Sengketa Batas Daerah pada Era Otonomi Daerah di Indonesia,” Yogyakarta, 2013.

[2] Kementerian Dalam Negeri, "Peraturan Menteri Dalam Negeri Republik Indonesia No.76 Tahun 2012 Tentang Pedoman Penegasan Batas Daerah," Jakarta, 2012.

[3] Kementerian Dalam Negeri, "Profil Daerah Kabupaten Donggala dan Kabupaten Mamuju Utara,” Jakarta, 2016. 